\title{
Generational and Cyclical Demographic Change in The Geological Society of America
}

Dallas D. Rhodes, Dept. of Geology and Geography, Georgia Southern University, Statesboro, Georgia 30460, USA

\section{INTRODUCTION}

The Geological Society of America's (GSA) membership is a demographic aggregate of individuals who join the Society, age as members, and eventually leave it either voluntarily or through death. GSA's population structure bears the imprint of the major events that have shaped the geosciences during the past 85 years (the lifetimes of its membership). The current population structure also anticipates future changes in the Society's membership.

GSA provided the birth year, gender, and location (state or country) of active members in July 2006; the data analyzed here include only members residing in the United States ( 15,224 members; $85.4 \%$ of the Society's total) to minimize demographic variations resulting from the varied social, political, and economic histories of multiple nationalities.

\section{DEMOGRAPHIC CHARACTERISTICS OF THE MEMBERSHIP}

Figure 1 illustrates the age and gender composition of the 2006 GSA membership sample. Members of each gender are organized into cohorts of individuals born within 5-year intervals.

GEOLOGICAL SOCIETY OF AMERICA (2006)

Male $(72.4 \%) \quad$ Percent of Total Membership $(\mathrm{N}=15,224 *) \quad$ Female $(27.6 \%)$

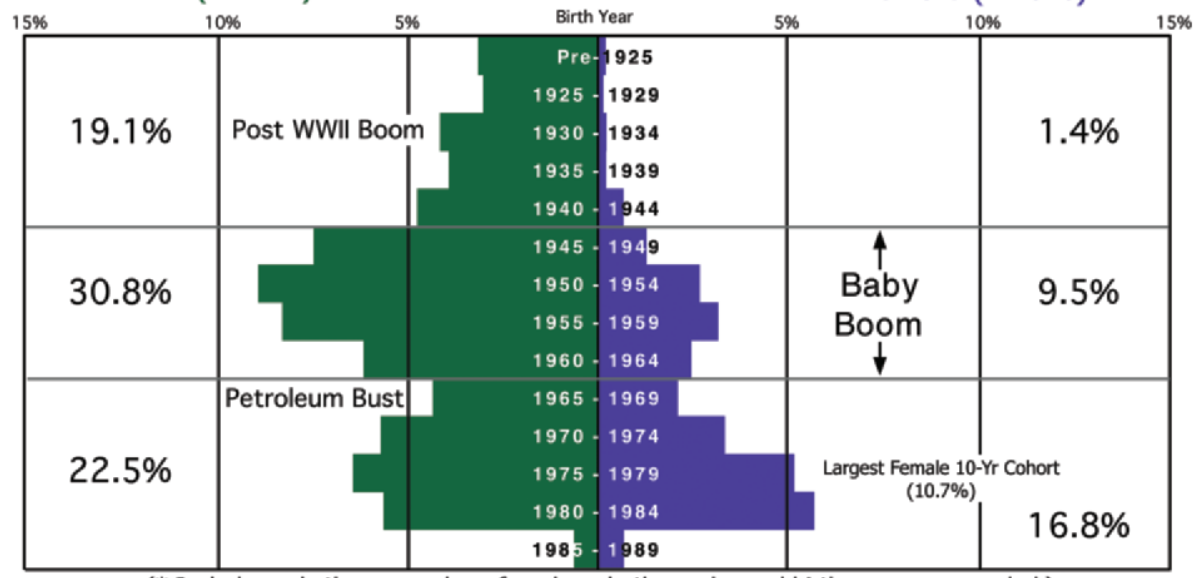

(* Includes only those members for whom both gender and birth year are recorded.)

Figure 1. Population structure pyramid for 15,224 members of the Geological Society of America residing in the United States in July 2006. Five-year cohorts are scaled as a percent of the sampled membership.

GSA Today, v. 18, no. 11, doi: 10.1130/GSATGW21A.1

drhodes@georgiasouthern.edu

\section{Gender Imbalance}

The most striking feature of GSA's population structure is the small percentage of women members-only $27.6 \%$. The gender imbalance is especially notable among those born prior to 1945 , when men outnumber women by more than 14 to 1 . Cohorts born after 1969 have many more female members, and the number has increased with each successive 5-year cohort. This change reflects the near equity of the genders in geoscience degrees now being awarded in the United States (Holmes and O'Connell, 2007).

\section{Post-World War II Expansion}

The bulge in GSA's membership corresponding to the timing of the Baby Boom (1946-1964) is one of the Society's most pronounced demographic features. The bulge is strongly asymmetric, with men in every cohort outnumbering women by more than 3 to 1 (30.8\% to $9.5 \%)$.

Unusually large cohorts born during the Baby Boom are not observed in all academic disciplines. The membership of the Association of American Geographers, for example, does not have particularly large cohorts from the Baby Boom years. In fact, the increase in the national birthrate that led to the Baby Boom appears to be only coincidentally associated with the large number of geoscientists born during those years. Federal programs to enhance the sciences and science education appear to have been far more important.

\section{Petroleum Boom-and-Bust Cycles}

Petroleum exploration in the United States is a story of "boom-and-bust" cycles (Deffeyes, 2001), and the two twentieth-century cycles had profound effects on GSA's membership. The first cycle began in August 1945, when the United States ended gasoline rationing. The boom, resulting from higher gas 
prices, continued until 1957, when "famine had replaced feast in the exploration business" (Friedman, 1978) and employment opportunities dwindled (Fig. 2).

The effects of the boom in oil prices are reflected by the bulge in the 1930-1934 birth-year cohort (Fig. 1). After the price bubble burst in 1957, employment opportunities for the following (1935-1939) cohort were significantly reduced.

The second and most prominent gap in GSA's membership resulted from the petroleum boom and bust of 1973-1986 driven by the Organization of Petroleum Exporting Countries (OPEC) and political unrest in the Middle East. The boom was initiated when the "oil weapon" was employed as part of the Arab strategy for the 1973 Yom Kippur War. The Iranian Revolution (begun Jan. 1978) and the Iran-Iraq War (begun Sept. 1980) drove the crude oil market price in "real" (uninflated) 2007 dollars to an historic high (www.wtrg.com/prices.htm) that was not exceeded until March 2008 (Fig. 2).

Writing for Science in 1978, Gerald Friedman proclaimed the years ahead to be "The Golden Age of the Geoscientist." Record oil prices produced the "greatest boom of them all" (Yergin, 1991), and employment opportunities for earth scientists had never been brighter (Rossbacher, 1983). Unfortunately, this "Golden Age" was short-lived, ending only three years after Friedman's prediction.

In the early 1980s, OPEC began to lose its power to dictate the world's petroleum prices. Saudi Arabia broke ranks with OPEC in 1981 and increased production to regain its market share and income. The price of petroleum fell immediately and continued to plummet until 1986, by which time the price in real dollars had returned to pre-embargo levels (Fig. 2). The impacts of this change on employment opportunities and education in the geosciences were immediate and devastating (Fig. 2).

The 1965-1969 birth cohort was college age (18-23) when the Middle East Petroleum Bust reached its nadir. Undergraduate enrollment in geoscience programs across the country plunged as jobs disappeared (AGI, 2001). In 1981, more than 7,000 geoscience undergraduate degrees were conferred in the United States, but by 1991, fewer than 2,000 were earned (Fig. 2)

\section{The Base of the Pyramid: After The Bust}

The disastrous decline in enrollment following the most recent bust placed many academic geoscience departments in jeopardy (Feiss, 1996). With students no longer drawn to the field by the prospect of large salaries, geoscience departments began to change in order to survive. New employment opportunities for geoscientists, driven largely by environmental issues, required a new curriculum.

In concert with curricular changes, academic departments and the geosciences at large began to accept pedagogy as a legitimate research area. GSA acknowledged this important change in 1991 with the creation of the Geoscience Education Division. Pressed by regional institutional accreditation, assessment in all its varied forms, budget constraints, and simple survival, many geoscience professors have focused on the scholarship of teaching and on finding ways to make the science more accessible.

Members added to GSA since the most recent petroleum bust mark a major demographic shift. The most important change is the decline in gender imbalance, reflecting increases in the number of women entering the geosciences (Fig. 2). Between 1974

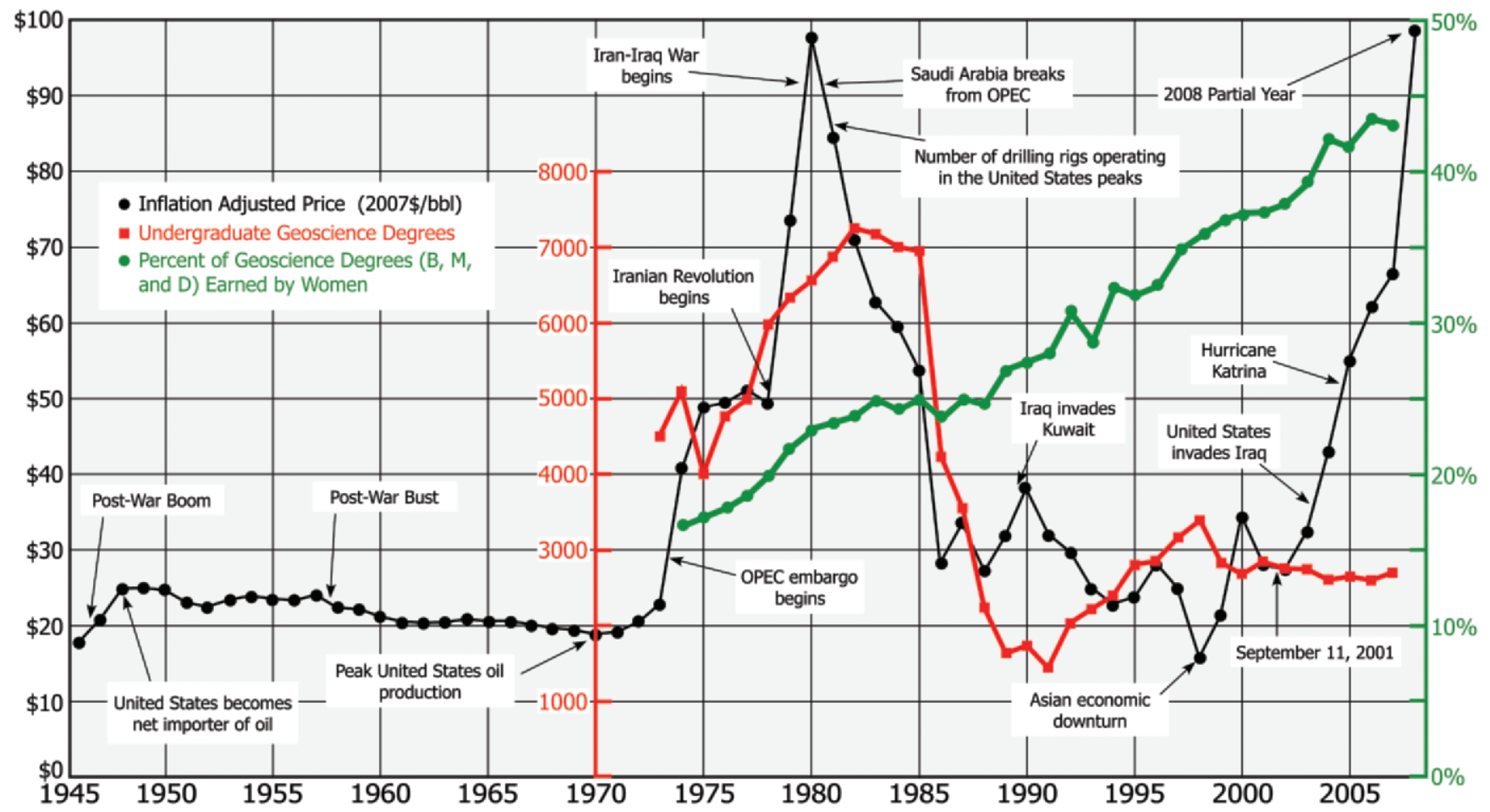

Figure 2. Geoscience degrees granted in the United States and the percentage of those degrees awarded to women from 1973 to 2007 . Data compiled by the American Geological Institute and cited by Keane (2005). Inflation adjusted (in 2007 U.S. dollars) annual average price of oil from 1946 through 2008 with significant events affecting the price. Data from http://inflationdata.com/inflation/Inflation_Rate/Historical_Oil_Prices_Table.asp citing as its source the United States Department of Energy (www.economagic.com) and www.imperialoil.com. 
and 2000, geoscience degrees awarded to women rose from $\sim 17 \%$ to $45 \%$ (AGI, 2001). With substantially fewer men joining GSA now than during the Baby Boomers' undergraduate and post-graduate years, the growth in women members has prevented a substantial loss in overall GSA membership.

\section{DISCUSSION}

Nothing in the current GSA structure dictates the size or composition of future cohorts. Reasonable predictions can, however, be made as the extant cohorts continue to age.

First, as GSA's Baby-Boom generation moves into retirement and leaves the organization, the Society's membership will decline substantially unless new members are added more rapidly. In 2006, slightly more than $45 \%$ of the Society's membership was 50 or older. The three largest male cohorts (Fig. 1) will all reach retirement age in the next 15 years. This loss is inevitable and can be counterbalanced only by producing more U.S. geoscientists or by bringing in geoscientists from other countries.

Second, the 1980s Petroleum-Bust cohorts (born 1965-1975) are just entering their 40 s and are assuming a much greater share of the responsibility for their profession. The small size of these cohorts means that there are fewer people to carry on the work of the science and the Society than in the past. Members of this group will, however, benefit from the increased opportunities for leadership. As well, some responsibilities that would usually be borne by this age group will probably be passed on to younger members.

Third, women are certain to play a larger role in the Society than ever before. It is critical, therefore, to retain as professionals women recruited as geoscience majors (de Wet et al., 2002).

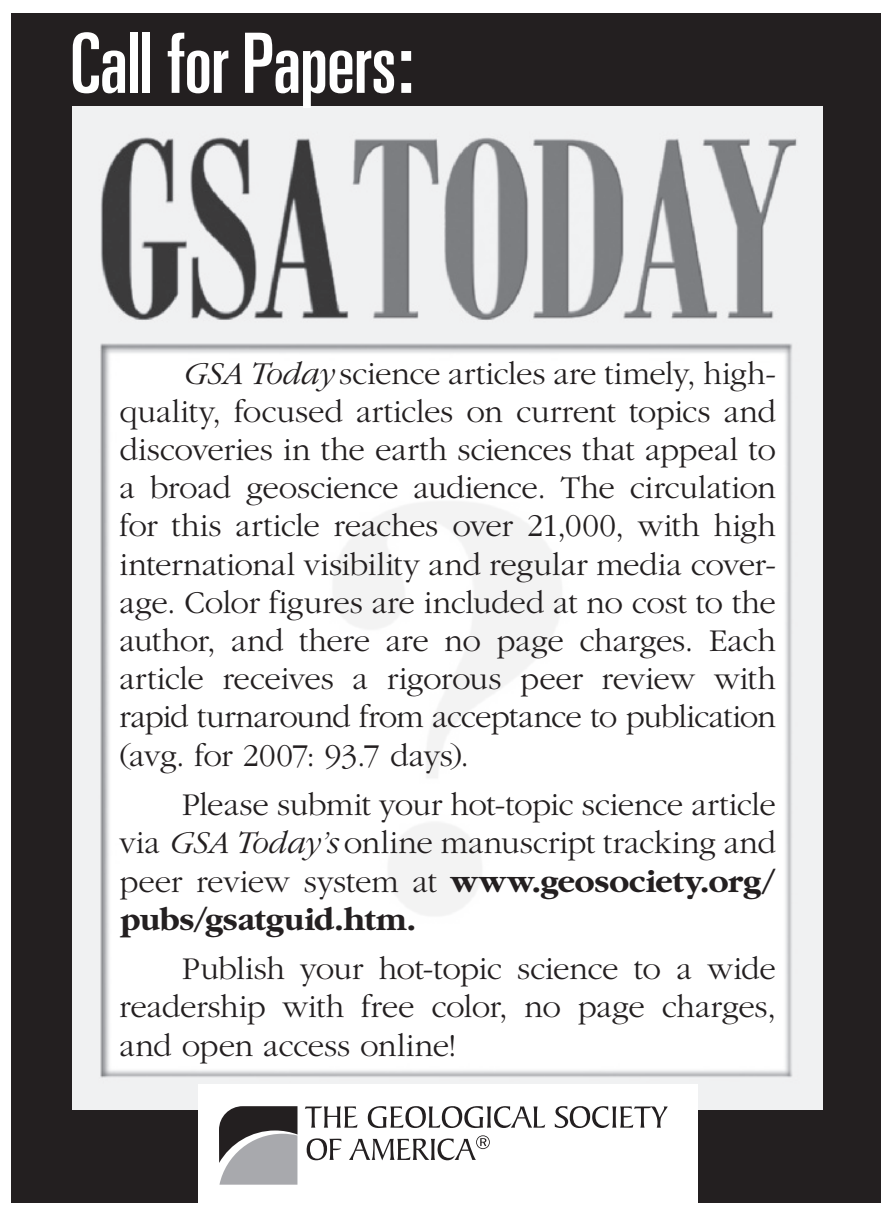

For most of GSA's history, the societal value of geoscience has been defined by the ability of geologists to discover mineral and petroleum resources. The events of more than 50 years ago still have a recognizable imprint on GSA's membership, but the oil boom-and-bust cycles that largely shaped the geosciences throughout the twentieth century may be over (Keane, 2005). If these cycles have ceased, or at least ceased to be the most important influence on GSA, the class of events that may have this role in the future is by no means clear. Political, economic, and social changes are certain to have a profound impact on the Society and its membership.

\section{REFERENCES CITED}

American Geological Institute (AGI), 2001, Report on the status of academic geoscience departments, $9 \mathrm{p}$.

Deffeyes, K.S., 2001, Hubbert's Peak: The impending world oil shortage: Princeton, New Jersey, Princeton University Press, 208 p.

de Wet, C.B., Ashley, G.M., and Kegel, D.P., 2002, Biological clocks and tenure timetables: Restructuring the academic timeline: GSA Today, v. 12 , no. 11, p. 1-7.

Feiss, P.G., 1996, The survival of academic geology programs: GSA Today, v. 6, no. 1 , p. $16-17$.

Friedman, G.M., 1978, The golden age of the geoscientist: Science, v. 201, p. 215, doi: $10.1126 /$ science.201.4352.215.

Holmes, M.A., and O'Connell, S., 2007, Leaks in the pipeline: Why do women remain curiously absent from the ranks of academia?: Nature, v. 446, 7133, p. 346, doi: 10.1038/nj7133-346a.

Keane, C.M., 2005, Out of boom and bust, but where now for geoscience departments: Eos (Transactions, American Geophysical Union) v. 85, no. 52 (Fall Meeting Supplement), p. ED12A-02.

Rossbacher, L.A., 1983, Career Opportunities in Geology and the Earth Sciences: New York, ARCO Publishing, 186 p.

Yergin, D., 1991, The Prize: The Epic Quest for Oil, Money and Power: New York, Simon \& Schuster, 877 p.

Manuscript received 28 June 2008; accepted 21 July 2008

\section{Apply to Participate Today!}

\section{Marine Geoscience Leadership Symposium March 23-27, 2009}

The Marine Geoscience Leadership Symposium is a new endeavor that crosses the boundaries between marine geology and geophysics and provides early career researchers with insight into leading a successful research career. The symposium will provide a forum for presenting cutting-edge research to peers and distinguished members of the scientific community and provide valuable leadership training, including knowledge of U.S. science agencies and effective techniques to approach decision makers and legislators. Participants will engage in small group discussions, participate in proposal writing workshops, and meet with funding agencies, media representatives, and policymakers.

Apply now to participate in an experience that will develop long-lasting, collaborative relationships between the newest generation of scientists. Eligible scientists must have completed their Ph.D. between December I, 2005 and December I, 2008 and be from any subfield of marine geology or geophysics.

For complete application instructions and more information, visit http://www.oceanleadership.org/mgls or contact Emily Powell at epowell@oceanleadership.org.

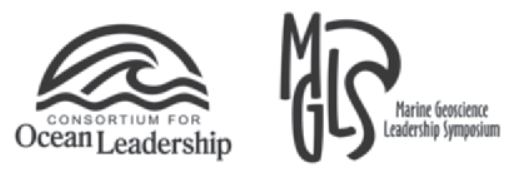

I20I New York Avenue, NW, Fourth Floor Washington, DC 20005 